\title{
My Hazara People ${ }^{1}$
}

\author{
Shukria Rezaei ${ }^{2}$ \\ Afghanistan/United Kingdom
}

[Article copies available for a fee from The Transformative Studies Institute. E-mail address: journal@transformativestudies.org Website: http://www.transformativestudies.org (C2020 by The Transformative Studies Institute. All rights reserved.]

I can't write about my Hazara people who have suffered for decades in Afghanistan where they come from in Pakistan where they are murdered in Iran where they offend because of their almond-shaped eyes my mind is blank!

I can't write about how loud the shooting was just two miles from my house.

How my aunt fainted.

How nervous my mom got, how the cup fell from her hand.

I can't write about how innocent people died, how the Martyr's necropolis gets bigger and bigger, how my people suffer, how cruel this world can get, how frightening it is

for kids like me.

\footnotetext{
${ }^{1}$ Printed with permission.

${ }^{2}$ Shukria Rezaei, a published and prize-winning poet, left her home Afghanistan to escape the ongoing attacks on the Hazara people by the Taliban. Following refuge in Pakistan, she and her mother moved on to Oxford to be reunited with her father. She won her first poetry prize at the age of fifteen, less than a year after her arrival in England. She now attends the University of London.
} 